\title{
GEODESY
}

\section{UDC 528.48}

\author{
V. CHIRIAC ${ }^{1}$, V. CICLICCI $^{2}$ \\ ${ }^{1}$ Department of Civil Engineering and Geodesy, Technical University of Moldova, 41, Dacia bd. of. 10, Chisinau, Republic of \\ Moldova, tel. +373 69295057, e-mail vasile.chiriac@gcg.utm.md \\ ${ }^{2}$ Societatea pe Acțiuni SOFTCOM, 76, Decebal bd., of. 703, Chisinau, Republic of Moldova, tel. +373 22563306, e-mail \\ vciclicci@gmail.com
}

https://doi.org/10.23939/istcgcap2020.91.005

\section{CALIBRATION OF AUTOMATED VERTICALITY MONITORING SYSTEM OF RADIO-COMMUNICATION MASTS AND TOWERS USING GEODETIC MEASUREMENTS}

The purpose of the study is the development of calibration methodology of automated verticality monitoring system of radio communication masts and towers using geodetic measurements in order to obtain corrections in inclinometer measurements relative to the construction's vertical axis. There are two different methods used for tower verticality determination: using Global Navigation Satellite Systems (GNSS) observations; three-dimensional terrestrial geodetic measurements using total station or traditional geodetic measurements methods. This paper is focused on using microelectromechanical systems (MEMS) dual axis inclinometer for small-angle measurements on the radio-communication tower to obtain changes relative to the structure of vertical axis. However, the initial inclination of the tower can be calculated by modelling the variables obtained from the inclinometer data in combination with geodetic measurements. The method of achieving this goal is provided by theoretical and experimental studies to perform assembly calibration errors using inclinometer data and total station measurements. The main result of the study is the possibility of taking into account the initial position of the MEMS sensor defined as the angle between inclinometer and masts and towers construction. Differences between the calculated and the measured by inclinometer pitch and roll angles at the same time give the correction to be applied to sensor data. Also, for high precision calibration of inclinometer sensors the influence of total station accuracy on determination of yawpitch-roll parameters has been estimated. Scientific novelty: Based on relationship between total station and platform topocentric coordinate systems the formulas for sensor platform orientation parameters calculation have been derived. Practical significance: the proposed methodology allows calibrating MEMS sensors installed on the radio communication masts and towers using total station measurements from single ground control point.

Key words: tower construction, masts, calibration, inclinometer, geodetic measurement, total station

\section{Introduction}

The worldwide ongoing process of using microelectromechanical systems (MEMS) technology for almost every possible sensing modality assume production of a variety of sensors for measuring pressure, motion, acceleration, temperature, magnetic field, and light, as well as gyroscopes, inclinometers, switches, capacitive touch sensors, etc. [Batusov, et al., 2014, 2015].

This paper is focused on using MEMS dual axis inclinometer for small-angle measurements on the radio-communication tower to obtain changes relative to the structure's vertical axis. In order to calculate corrections in inclinometer data due to the irregularity of reference surfaces the calibration methodology of automated verticality monitoring system of radio communication masts and towers using geodetic measurements has been developed.
Inclinometers installed on the radio-communication mast are connected through thunderprotection modules to a common cable transmitting data at intervals of 50 milliseconds through an RS-485 interface. The lower end of the RS-485 cable is connected to the host-controller for communications with sensors and a $3 \mathrm{G}$ modem to ensure data exchange with web-portal server installed in the main office of S. A. SOFTCOM Company.

Web-portal server stores the sensor data received via the Internet from a $3 \mathrm{G}$ modem. Server application software processes the sensor data array and ensures the user interface for displaying information (real time oscillations, mast inclinations and alarm map). The user gets access to the server via the Internet to the workstation (see Fig. 1).

In most cases it is very difficult to install an inclinometer sensor on the metal details of the 
tower construction exactly in the horizontal position perpendicular to the plumb line. In order to calibrate the inclinometer on the tower it is necessary to know the initial inclination of the construction defined as the angle between the gravity vector and vertical axis of the construction.

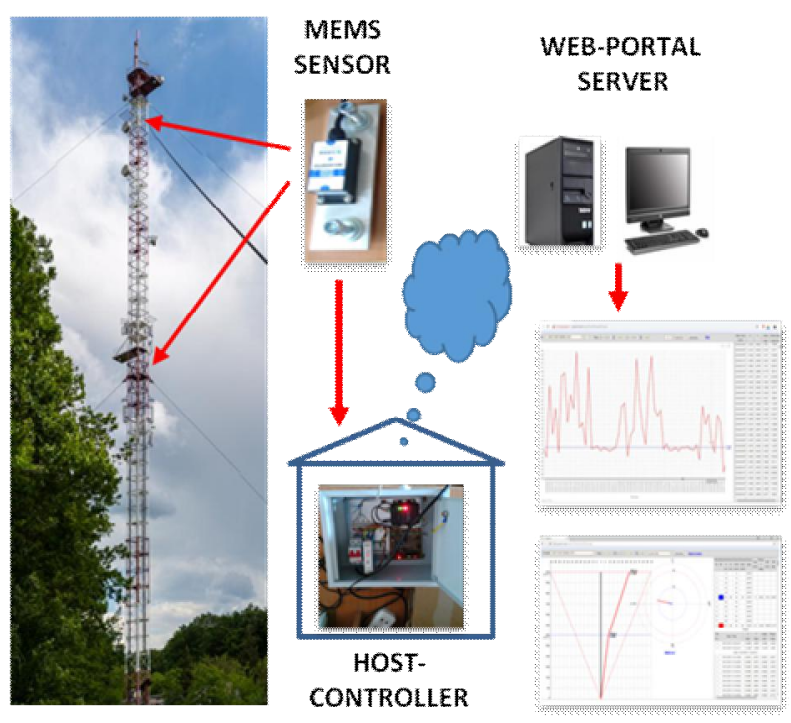

Fig. 1. Automated verticality monitoring system architecture (photos by authors)

There are different methods of tower verticality determination using Global Navigation Satellite Systems (GNSS) observations, three-dimensional terrestrial geodetic measurements using total station, or traditional geodetic measurements methods well described by different authors [Franceschini, et al., 2014; Roberts, et al., 2004; Keong, 1999; Widerski, \& Kurałowicz, 2014].

The radio communication masts and towers verticality determination from GNSS observations is mostly used for tower and mast deformation monitoring and is expensive method for inclinemeter calibration. The traditional trigonometric method requires observations obtained from three positions located around the communication masts and towers and it is difficult to be used because for inclinometer calibration it is necessary to have simultaneous measurements from three ground control points. The existing total station measurement methods require observations obtained from at least two ground control points that also is difficult to use in the forest were sometimes only one ground control point is accessible.

In this paper, a precise mathematical model based on inclinometer data and total station measurements is proposed in order to perform assembly calibration errors using single ground control point. Also the accuracy of proposed calibration methodology was estimated using the high precision total station measurements.

The purpose of this study is the development of calibration methodology of automated verticality monitoring system of radio communication masts and towers using geodetic measurements in order to obtain corrections in inclinometer measurements relative to the construction of vertical axis.

The preliminary investigations show the possibility to install MEMS dual axis inclinometer for small-angle measurements on the radiocommunication tower to obtain changes relative to the construction of vertical axis.

The initial position of the MEMS sensor defined as the angles between inclinometer axes and towers construction can be calculated from the total station measurements from the single ground control point using for control measured distances between prisms mounted at the corners of the platform with inclinometer installed in the middle of the metal bar.

\section{Methodology and research results}

Based on relationship between total station and platform topocentric coordinates (see Fig. 2) the formulas for sensor platform orientation parameters were derived [Gao, et al., 2016; Kim, et al., 2013; Luhmann, 2009; Liu, et al., 2013; Li, 2014; Zhang, 2000].

Relationship between orientation angle (yaw) $\alpha$, vertical angle $z$, distance $s$ and total station system of coordinates $N_{T S}, E_{T S}, U_{T S}$ are well-known as the following:

$$
\left[\begin{array}{c}
N_{T S} \\
E_{T S} \\
U_{T S}
\end{array}\right]=S\left[\begin{array}{c}
\sin z \cos \alpha \\
\sin z \sin \alpha \\
\cos z
\end{array}\right] .
$$

Geodetic topocentric coordinates $N_{T S}^{\prime} E_{T S}^{\prime} U_{T S}^{\prime}$, could be determined by using translation vector $[\Delta N, \Delta E, \Delta U]^{\mathrm{T}}$ from total station system of coordinate $N_{T S}, E_{T S}, U_{T S}$ to sensor platform system of coordinate (see Fig. 2):

$$
\left[\begin{array}{c}
N_{T S}^{\prime} \\
E_{T S}^{\prime} \\
U_{T S}^{\prime}
\end{array}\right]=\left[\begin{array}{c}
N_{T S} \\
E_{T S} \\
U_{T S}
\end{array}\right]-\left[\begin{array}{c}
\Delta N \\
\Delta E \\
\Delta U
\end{array}\right] .
$$

Relationship between geodetic topocentric coordinates $N_{T S}^{\prime}, E_{T S}^{\prime}, U_{T S}^{\prime}$, and sensor platform 
system of coordinates $N^{\prime \prime}{ }_{P T}, E^{\prime \prime}{ }_{P T}, U^{\prime \prime}{ }_{P T}$ are defined by rotation matrix:

were:

$$
R=R_{\alpha} \times R_{\beta} \times R_{\gamma},
$$

$$
\begin{aligned}
& R_{\alpha}=\left[\begin{array}{ccc}
\cos \alpha & -\sin \alpha & 0 \\
\sin \alpha & \cos \alpha & 0 \\
0 & 0 & 1
\end{array}\right], \\
& R_{\beta}=\left[\begin{array}{ccc}
\cos \beta & 0 & \sin \beta \\
0 & 1 & 0 \\
-\sin \beta & 0 & \cos \gamma
\end{array}\right], \\
& R_{\gamma}=\left[\begin{array}{ccc}
1 & 0 & 0 \\
0 & \cos \gamma & -\sin \gamma \\
0 & \sin \gamma & \cos \gamma
\end{array}\right] .
\end{aligned}
$$

In order to identify origin and the orientation angle $\alpha$ of platform coordinate system the translation vector could be considered topocentric coordinates of prism $\mathrm{P}_{1}$ :

$$
\left[\begin{array}{c}
N_{T S}^{\prime} \\
E_{T S}^{\prime} \\
U_{T S}^{\prime}
\end{array}\right]_{P 2}=\left[\begin{array}{c}
N_{T S} \\
E_{T S} \\
U_{T S}
\end{array}\right]_{P 2}-\left[\begin{array}{c}
N_{T S} \\
E_{T S} \\
U_{T S}
\end{array}\right]_{P 1} .
$$

The orientation angle $\alpha$ can be determined from differences of topocentric coordinates of point $\mathrm{P}_{2}$ and point $P_{1}$ :

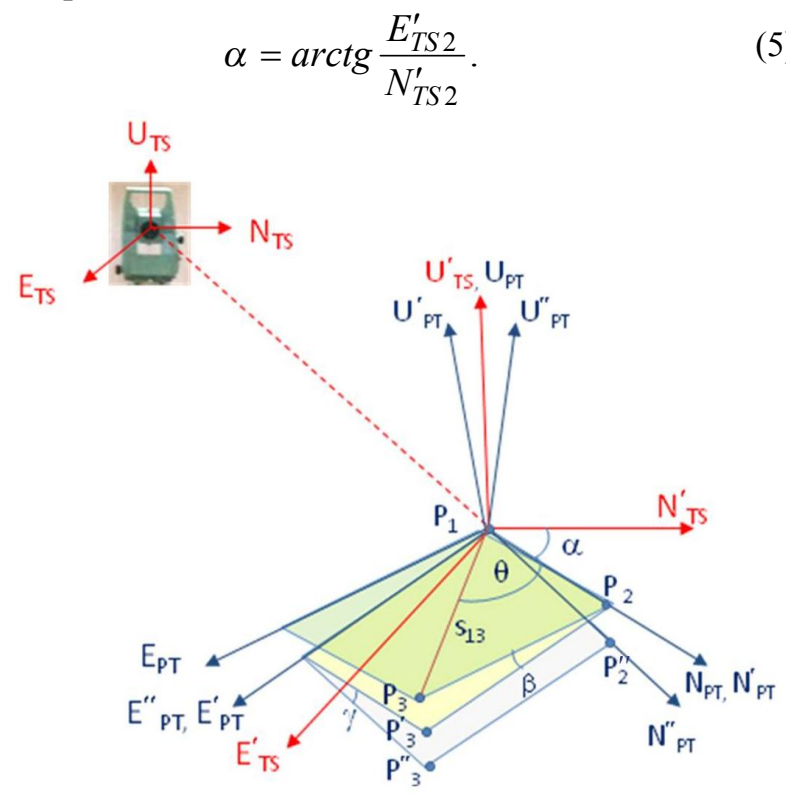

Fig. 2. Relationship between total station and sensor platform topocentric coordinate systems

Once the orientation angle $\alpha$ is obtained as in equations (5) a sensor platform could be oriented by rotation matrix $R_{\alpha}$ around axis $U_{T S}^{\prime}$ :

$$
\begin{gathered}
{\left[\begin{array}{c}
N_{T S}^{\prime} \\
E_{T S}^{\prime} \\
U_{T S}^{\prime}
\end{array}\right]_{P 3}=\left[\begin{array}{c}
N_{T S} \\
E_{T S} \\
U_{T S}
\end{array}\right]_{P 3}-\left[\begin{array}{c}
N_{T S} \\
E_{T S} \\
U_{T S}
\end{array}\right]_{P 1},} \\
{\left[\begin{array}{c}
N_{P T} \\
E_{P T} \\
U_{P T}
\end{array}\right]_{P 3}=\left[\begin{array}{ccc}
\cos \alpha & -\sin \alpha & 0 \\
\sin \alpha & \cos \alpha & 0 \\
0 & 0 & 1
\end{array}\right] \times\left[\begin{array}{c}
N_{T S}^{\prime} \\
E_{T S}^{\prime} \\
U_{T S}^{\prime}
\end{array}\right]_{P 3} .}
\end{gathered}
$$

Taking in account equations (6) the pitch angle $\beta$ could be determined from differences of total station coordinates of point $\mathrm{P}_{3}$ and point $\mathrm{P}_{1}$ :

$$
\beta=\operatorname{arctg} \frac{U_{T S 3}^{\prime}}{E_{P T 3}} .
$$

After the orientation $\alpha$ and pitch $\beta$ angles are obtained as in equations $(5,7)$, the relations between platform coordinate systems could be established:

$$
\begin{aligned}
& {\left[\begin{array}{l}
N_{P T}^{\prime} \\
E_{P T}^{\prime} \\
U_{P T}^{\prime}
\end{array}\right]_{P 3}=\left[\begin{array}{ccc}
\cos \beta & 0 & \sin \beta \\
0 & 1 & 0 \\
-\sin \beta & 0 & \cos \beta
\end{array}\right] \times\left[\begin{array}{c}
N_{P T} \\
E_{P T} \\
U_{P T}
\end{array}\right]_{P 3},} \\
& {\left[\begin{array}{c}
N_{P T}^{\prime \prime} \\
E_{P T}^{\prime \prime} \\
U_{P T}^{\prime \prime}
\end{array}\right]_{P 3}=\left[\begin{array}{ccc}
1 & 0 & 0 \\
0 & \cos \gamma & -\sin \gamma \\
0 & \sin \gamma & \cos \gamma
\end{array}\right] \times\left[\begin{array}{c}
N_{P T}^{\prime} \\
E_{P T}^{\prime} \\
U_{P T}^{\prime}
\end{array}\right]_{P 3} .}
\end{aligned}
$$

Taking in account that a third rotation by roll angle $\gamma$, rotates the prism $\mathrm{P}_{3}$ coordinates $N_{P T 3}^{\prime}$, $E_{P T 3}^{\prime}, U_{P T 3}^{\prime}$ to its platform frame $U_{P T}^{\prime \prime}=0$. From last row the roll angle $\gamma$ could be derived as following:

$$
\sin \gamma \cdot E_{P T 3}^{\prime}+\cos \gamma \cdot U_{P T 3}^{\prime}=0,
$$

therefore the roll angle $\gamma$ can be determined from the prism $\mathrm{P}_{3}$ coordinates:

$$
\gamma=-\operatorname{arctg} \frac{U_{P T 3}^{\prime}}{E_{P T 3}^{\prime}} .
$$

For control of pitch angle $\beta$ and roll angle $\gamma$ determination using equations (7), (9) we can calculate coordinates $N^{\prime \prime}{ }_{P T 3}$ and $E^{\prime \prime}{ }_{P T 3}$ using measured distance $S_{13}$ and angle $\theta$ between axis $N_{P T}$ and direction from prism $\mathrm{P}_{1}$ to prism $\mathrm{P}_{3}$ :

$$
N_{P T 3}^{\prime \prime}=S_{13} \cdot \cos \theta, \quad E_{P T 3}^{\prime \prime}=S_{13} \cdot \sin \theta,
$$

were angle $\theta$ could be easy calculated from triangle $\Delta \mathrm{P}_{1} \mathrm{P}_{2} \mathrm{P}_{3}$ (see Fig. 2):

$$
\theta=\operatorname{arctg} \frac{E_{P T 3}}{N_{P T 3}} .
$$


The accuracy $m_{\beta}$ and $m_{\gamma}$ of the pitch $\beta$ and roll $\gamma$ angles can be calculated using the coordinate calculation errors $m_{U}, m_{N E}$, distance $S_{13}$ and angle $\theta$ between axis $N_{P T}$ and direction from prism $\mathrm{P}_{1}$ to prism $\mathrm{P}_{3}$ :

$$
m_{\beta}=\frac{m_{U}}{S}, \quad m_{\gamma}=\frac{m_{N E}}{S \cdot \cos \theta} .
$$

In order to validate the calibration method on the Ivantseva radio-communication tower $(\mathrm{h}=117.35 \mathrm{~m})$ two dual-axis Bewis Sensing inclinometers were installed with accuracy $0.01^{\circ}$ at the $49.85 \mathrm{~m}$ level and $0.001^{\circ}$ at the $85.85 \mathrm{~m}$ level (see Fig. 1).

Taking in consideration the distance from ground control point $\mathrm{ST}_{1}$ to the tower construction is around $110 \mathrm{~m}$ and platform size is around $2.5 \times 2.5$ meters the Leica Geosystems total station TC802 with accuracy $\mathrm{m}_{\alpha}= \pm 2$ and $\mathrm{m}_{\mathrm{s}}= \pm(2+2 \mathrm{ppm}) \mathrm{mm}$ that ensured coordinate calculation with $2.5 \mathrm{~mm}$ accuracy was selected.

The influence of distances between prisms on pitch and roll angles determination accuracy calculated for $m_{U}=m_{N E}=2.5 \mathrm{~mm}$ according equations (10) is shown on the diagram (Fig. 3).

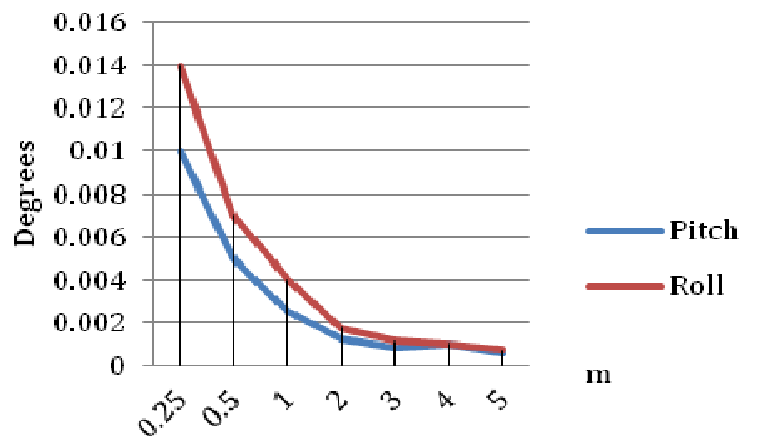

Fig. 3. The influence of distances between prisms on pitch and roll angles determination accuracy.

In order to ensure the inclinometer calibration accuracy for this kind of tower construction the prisms $\mathrm{P}_{1}, \mathrm{P}_{2}$ were mounted at the ends of the 2.5 meters metal bar with inclinometer installed in the middle and the prism P3 mounted at the end of perpendicular metal bar (Fig. 4).

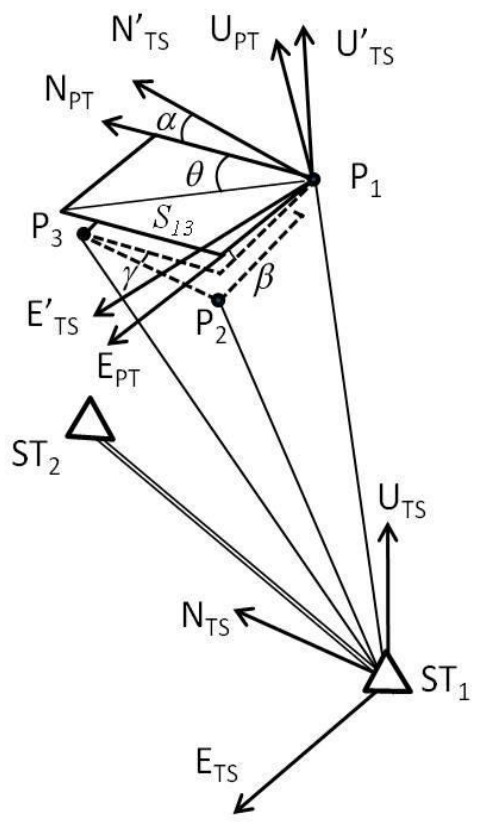

Fig. 4. The scheme of geodetic measurements

The total station measurements to the prisms $\mathrm{P}_{1}$, $\mathrm{P}_{2}, \mathrm{P}_{3}$ were done from the ground control point $\mathrm{ST}_{1}$ with orientation to ground control point $\mathrm{ST}_{2}$ installed at a distance of $105.759 \mathrm{~m}$ near to the tower construction.

The coordinates of control points $\mathrm{ST}_{1}, \mathrm{ST}_{2}$ were determined by Leica Viva GS15 GNSS receiver using national positioning system MOLDPOS.

Differences of the calculated and the measured by inclinometer pitch and roll angles, at the same time, give the corrections to pitch angle $\Delta \beta$ and roll angle $\Delta \gamma$ to be applied to sensor data (see Table).

The results show the possibility to use this calibration method in order to determine the initial position of the inclinometer installed on the tower construction.

Comparison of calculated and measured by inclinometer pitch and roll angles

\begin{tabular}{|c|c|c|c|c|c|c|}
\hline & $\begin{array}{c}\text { Measured } \\
\text { pitch angle } \\
\left(\beta_{m}^{\circ}\right)\end{array}$ & $\begin{array}{c}\text { Calculated } \\
\text { pitch angle } \\
\left(\beta_{\mathrm{c}}^{\circ}\right)\end{array}$ & $\begin{array}{c}\text { Correction } \\
{ }^{\circ}=\left(\beta_{\mathrm{c}}^{\circ}-\beta_{m}^{\circ}\right)\end{array}$ & $\begin{array}{c}\text { Measured } \\
\text { roll angle } \\
\left(\gamma_{m}^{\circ}\right)\end{array}$ & $\begin{array}{c}\text { Calculated } \\
\text { pitch angle } \\
\left(\gamma_{\mathrm{c}}^{\circ}\right)\end{array}$ & $\begin{array}{c}\text { Correction } \\
\Delta \gamma^{\circ}=\left(\gamma_{\mathrm{c}}^{\circ}-\gamma_{m}{ }^{\circ}\right)\end{array}$ \\
\hline $\begin{array}{c}\text { Inclinometer 1 } \\
h=49.85 \mathrm{~m}\end{array}$ & 0.2999 & 0.5353 & 0.2354 & -0.0213 & -0.0973 & -0.0760 \\
\hline $\begin{array}{c}\text { Inclinometer 2 } \\
h=85.85 \mathrm{~m}\end{array}$ & 0.2998 & 0.41626 & 0.1165 & 0.0780 & 0.1398 & 0.0618 \\
\hline
\end{tabular}


Publication is funded by the Polish National Agency for Academic Exchange under the International Academic Partnerships Programme from the project ,Organization of the 9th International Scientific and Technical Conference entitled Environmental Engineering, Photogrammetry, Geoinformatics - Modern Technologies and Development Perspectives".

\section{Conclusions}

1. The proposed methodology based on the relationship between total station topocentric coordinate system and inclinometer platform coordinate system allow to determine the sensor platform orientation parameters from one ground control point using total station measurements.

2. The results of investigations show the necessity to use at least 2 arcsec and $2 \mathrm{~mm}+2 \mathrm{ppm}$ precision total stations in order to calibrate inclinometer sensors on the tower construction with a level of precision comparable to the angular accuracy achievable by 0.001 degrees precision inclinometers.

3. The geodetic method used for determination of yaw-pitch-roll parameters should be used for installation of inclinometer sensors in order to avoid any influence of construction details due to the irregularity of reference surfaces.

4. In order to derive yaw, pitch and roll angles from total station measurements at least three reference markers have to be installed on the tower platform taking into consideration the possibility of increasing distances between them for high precision calibration of inclinometer sensors.

5 . The agreement between inclinometer measurements and independent geodetic methods of computing yaw-pith-roll parameters shows the necessity to continue investigations on different radiocommunication tower constructions using total station measurements in combination with GNSS observations. Future investigations should be orientted on combinations of total station measurements with GNSS observations in order to increase the accuracy of installation of inclinometer sensors.

6 . This methodology could be extended to the high-rise buildings deformation monitoring taking in account possibilities to install a single Automated Motorized Total Station.

Publication is funded by the Polish National Agency for Academic Exchange under the
International Academic Partnerships Programme from the project "Organization of the 9th International Scientific and Technical Conference entitled Environmental Engineering, Photogrammetry, Geoinformatics - Modern Technologies and Development Perspectives".

\section{REFERENCES}

Batusov, V., Budagov, J., Lyablin, M., Shirkov, G., Gayde, J. C., Di Girolamo, B., Mergelkuhl, D., \& Nessi, M. (2014). The Laser Reference Line Method and Its Comparison to a Total Station in an ATLASLike Configuration. Physics of Particles and Nuclei Letters, 11(3), 299-308.

Batusov, V., Budagov, J., Lyablin, M., Shirkov, G., Gayde, J. C., \& Mergelkuhl, D. (2015). The calibration of the precision laser inclinometer. Physics of Particles and Nuclei Letters, 12(7), 819-823.

Franceschini, F., Galetto, M., Maisano, D. \& Mastrogiacomo, L. (2014). Large-scale dimensional metrology (LSDM): from tapes and theodolite to multi-sensor systems. International Journal of Precision Engineering and Manufacturing, 15(8), 1739-1758.

Gao, Y., Lin, J., Yang, L., \& Zhu, J. (2016). Development and calibration of an accurate 6-degree-of-freedom measurement system with total station. Measurement Science and Technology, 27(12), 125103.

Keong, I. (1999). Determining Heading and Pitch Using a Single Difference GPS/GLONASS Approach. UCGE Reports, Number 20134, Calgary, Alberta.

Kim, Y. K., Kim, Y., Jung, Y. S., Jang, I. G., Kim, K. S., Kim, S., \& Kwak, B. M. (2012). Developing accurate long-distance 6-DOF motion detection with onedimensional laser sensors: Three-beam detection system. IEEE Transactions on Industrial Electronics, 60(8), 3386-3395.

Luhmann, T. (2009). Precision potential of photo-grammetric 6DOF pose estimation with a single camera. ISPRS Journal of Photogrammetry and Remote Sensing, 64(3), 275-284.

Liu, Z., Zhu, J., Yang, L., Liu, H., Wu, J. \& Xue, B. (2013). A single station multi-tasking 3D coordinate measurement method. Measurement Science and Technology. 24(10): 105004.

Li, Y. H., Qiu, Y. R., Chen, Y. X. \& Guan, K. S. (2014). A novel orientation and position measuring system for large and dium scale precision assembly. Optics and Lasers in Engineering, 2014, 62: 31-37.

Roberts, G. W., Meng, X. L. \& Dodson A. H. (2004). Integrating a Global Positioning System and accelerometers to monitor the deflection of 
bridges. Journal of Surveying Engineering, 130(2), 65-72.

Roberts, G. W., Cosser, E., Meng, X., \& Dodson, A. (2004). High frequency deflection monitoring of bridges by GPS. Journal of Global Positioning Systems, 3(1-2), 226-231.
Zhang, Z. (2000). A flexible new technique for camera calibration. IEEE Transactions on pattern analysis and machine intelligence, 22(11), 1330-1334.

Widerski, T. \& Kurałowicz, Z. (2014). Geodesic monitoring of tower and mast structures. Reports on Geodesy, $411-417$.

\section{В. КІРІЯК ${ }^{1}$, В. ЧІКЛІКЧІ}

${ }^{1}$ кафедра будівництва та геодезії Технічного університету Молдови, вул. Dacia, 41, оф. 10, Кишинів, Республіка Молдова, тел. +373 69295057, ел. пошта: vasile.chiriac@gcg.utm.md

${ }^{2}$ Societatea pe Acțiuni SOFTCOM, вул. Decebal, 76, оф. 703, Кишинів, Республіка Молдова, тел. +373 22563306, ел. пошта: vciclicci@gmail.com

\section{КАЛІБРАЦІЯ АВТОМАТИЗОВАНОЇ СИСТЕМИ МОНТТОРИНГУ ВЕРТИКАЛЬНОСТІ РАДІОКОМУНІКАЦЙНИХ ЩОГЛ ТА ВЕЖ З ВИКОРИСТАННЯМ ГЕОДЕЗИЧНИХ ВИМІРЮВАНЬ}

Метою дослідження $\epsilon$ розробка методики калібрування автоматизованої системи моніторингу вертикальності щогл та веж радіозв'язку з використанням геодезичних вимірювань 3 метою отримання поправок в інклінометричних вимірах щодо вертикальної осі конструкції. Існують два різні методи, які використовуються для визначення вертикальності вежі: використання спостережень глобальних навігаційних супутникових систем (GNSS); тривимірні наземні геодезичні вимірювання з використанням тахеометрів або традиційних методів геодезичних вимірювань. Ця стаття зосереджена на використанні мікроелектромеханічних систем (MEMS) з двоклінічним інклінометром для вимірювання малих кутів на радіокомунікаційній вежі для отримання змін відносно вертикальної осі конструкції. Однак початковий нахил вежі можна обчислити, моделюючи змінні, отримані з даних інклінометрів у поєднанні з геодезичними вимірюваннями. The method of achieving this goal is provided by theoretical and experimental studies to perform assembly calibration errors using inclinometer data and total station measurements. The main result of the study is the possibility of taking into account the initial position of the MEMS sensor defined as the angle between inclinometer and masts and towers construction. Differences between the calculated and the measured by inclinometer pitch and roll angles at the same time give the correction to be applied to sensor data. Also, for high precision calibration of inclinometer sensors the influence of total station accuracy on determination of yaw-pitch-roll parameters was estimated. Scientific novelty: Based on relationship between total station and platform topocentric coordinate systems the formulas for sensor platform orientation parameters calculation were derived. Practical significance: the proposed methodology allows calibrating MEMS sensors installed on the radio communication masts and towers using total station measurements from single ground control point. Метод досягнення цієї мети забезпечується теоретичними та експериментальними дослідженнями для виконання збору помилок калібрування 3 використанням даних інклінометрів та вимірювань за допомогою тахеометрів. Основним результатом дослідження $\epsilon$ можливість врахування вихідного положення датчика MEMS, визначеного як кут між інклінометром та конструкцією щогл та веж. Різниці між обчисленими та виміряними нахилами інклінометра та кутами нахилу одночасно дають коригування, яке слід застосувати до даних датчика. Крім того, для високоточної калібрування датчиків інклінометрів був оцінений вплив точності тахеометра на визначення параметрів відхилень. Наукова новизна: На основі співвідношення загальної станції та топоцентричної системи координат були отримані формули для розрахунку параметрів орієнтації платформи датчика. Практичне значення: запропонована методологія дозволяє калібрувати датчики MEMS, встановлені на щоглах і вежах радіозв'язку, використовуючи вимірювання тахеометром з однієї опорної точки.

Ключові слова: конструкція вежі, щогли, калібрування, інклінометр, геодезичне вимірювання, тахеометр

Received 30.12.2019 